University of Nebraska - Lincoln

DigitalCommons@University of Nebraska - Lincoln

$10-3-2020$

\title{
Public and Private (Dis)Incentives for Animal Identification
}

Elliott James Dennis

University of Nebraska - Lincoln, elliott.dennis@unl.edu

Follow this and additional works at: https://digitalcommons.unl.edu/ageconfarmmgmt

Part of the Agribusiness Commons, Entrepreneurial and Small Business Operations Commons, Management Information Systems Commons, Other Business Commons, and the Other Economics Commons

Dennis, Elliott James, "Public and Private (Dis)Incentives for Animal Identification" (2020). Extension Farm and Ranch Management. 54.

https://digitalcommons.unl.edu/ageconfarmmgmt/54

This News Article is brought to you for free and open access by the Agricultural Economics Department at DigitalCommons@University of Nebraska - Lincoln. It has been accepted for inclusion in Extension Farm and Ranch Management by an authorized administrator of DigitalCommons@University of Nebraska - Lincoln. 


\section{Public and Private (Dis)Incentives for Animal Identification}

Dr. Elliott Dennis, Assistant Professor, Livestock Marketing Economist, Department of Agricultural Economics, University of Nebraska - Lincoln

October 3, 2020

This article was first published by the Nebraska Cattleman.

There has been a growing global trend towards automating data collection and using captured data to inform decision-making. This has spilled over into the beef complex where packers, feedlots, and cow-calf producers seek to leverage information on animal performance, health, and welfare. The technology to automate data collection, commonly advocated as a way to manage and identify cattle, diverges from the traditional means of identifying cattle through brands. This article reviews how common different animal identification practices are for feedlots and cow-calf producers in the United States and the public and private (dis)incentives for animal identification.

\section{Historical Methods to Identify Cattle}

The methods used to identify feeder cattle has largely stayed unchanged in cow-calf operations. In a 2018 survey, 93\% of US cow calf producers identified either hot branding or the basic ear tag as their primary method for identifying cattle (Martin et al. 2020). The newer low and high frequency electronic ear tags (EID), freeze branding, and tattoos were each used by about 2-3\% of respondents, respectively. Categorizing operators by Beef Quality Assurance (BQA) certification showed that if producers were BQA certified they were twice as likely to use EID and freeze branding as a method of identification.

The share of cattle arriving at feedlots with EID in place is larger than cow-calf operator's use of EID to manage cattle. This seems to suggest that EID tags are placed in some feeder cattle prior to shipping rather than a primary means of identifying from birth to feedlot placement. In a 2011 national survey of feedlots, approximately $30 \%$ of feeder calves arriving at feedlots had EID tags. Operational size had little impact on feeder cattle being placed with EID tags. The exception was 500-999 head feedlots which had 58\% of placed feeder cattle with EID tags intact upon arrival.

The type method used by some feedlots for identifying cattle has changed considerably over time. For example, the percentage of feedlots with less than 1000 head one time capacity using branding as a method to identify cattle has stayed relatively stable since the $1990 \mathrm{~s}-11.2 \%$ used it in 1994 and 10.2\% used it in 2011. Feedlots with greater than 1000 head one time capacity use of branding has been declining - $42.9 \%$ used it in 1994, 38.5\% in 1999, and $22.5 \%$ in 2011. One reason why larger feedlots have been trending away from the use of brands is the increased desire to manage animal health, manage cattle in programs, animal welfare concerns, and the value of hides. 


\section{Public and Private Incentives for Electronic Identification}

Private incentives center on capturing market premiums passed down from consumers based on management and health treatment protocols. For example, organic meat prices are approximately $60 \%$ higher than commercial beef (USDA-AMS, 2020). Retails stores pass these premium incentives to packers who are willing to pay $\$ 31 /$ cwt for All Natural carcasses and $\$ 10$ for non-hormone treated (NHTC) carcasses (USDA-AMS, 2020). Feedlots pass this on to cow-calf producers by paying a $1.1 \%$ premium for All Natural calves and $2.7 \%$ premium for All Natural yearlings at auction (Blank et al. 2016). Cost is the primary disincentive cited for lack of use. EID tag + equipment + software costs as high. Even with large quantity purchases of EID tags and software in place, some large feedlots have stopped using EID tags on every animal citing the markets lack of ability to cover these added costs. Thus, while premiums do exist, they may not be high enough to compensate producers for the added costs to management.

Public incentives center on prevention and tracking of foreign animal disease. Bovine Spongiform Encephalopathy (BSE) is commonly cited as the "case-study". The US lost access to major exporting countries many of which did not recover to post BSE levels for approximately 10 years. Foot and Mouth Disease (FMD), currently not in the United States, is the most commonly cited "next" foreign animal disease to enter the US. Research suggests that if FMD were to enter the US, 10-year long run costs to the beef complex would total between $\$ 33$ and $\$ 93$ billion dollars (Schroeder et al., 2014). Public disincentives center on the lack of a foreign animal disease pre and post BSE. This approach views BSE as an abnormal event rather than a future normal. Likewise, claims suggest cumulative short-term losses are likely larger than post term recovery damages. While this could be true, it relies on accurate prediction of both frequency and market impacts of a future event to make substantiated claims.

\section{Summary and Implications}

Animal health identification and management has and will continue to change. EID is just on the many non-branding identification methods being adopted. It is importance to note that adoption is not always an "all-or-none" endeavor. Some have adopted a middle ground approach. For example, some feedlots and cow-calf producers only use EID on feeder cattle that are in special programs or where additional animal health protocols are required. This "hybrid" approach is one way producers have tried to reduce costs of non-branding identification tools while also trying to capture market premiums. Whatever the approach to animal identification, make sure the market is willing to pay and meets your operations long term goals for sustainability. 